\title{
ZELFMANAGEMENT \\ SUCCES EN FAALFACTOREN BIJ DE AUTONOMISERING \\ VAN WERKGROEPEN
}

\author{
door Dr.J. Kastelein
}

\section{Inleiding}

In de kakofonie van termen, die in verband worden gebracht met pogingen om organisaties te democratiseren en de leden ervan te motiveren tot participatie, valt ook het woord groepsautonomie of zelfmanagement nogal eens. Ik ben in mijn werk op verschillende manieren bij autonomiseringsvraagstukken betrokken geweest en ik wil graag van deze gelegenheid gebruik maken om mijn huidige visie te geven op de wenselijkheid ván en de voorwaarden vóór autonomiebevordering bij kleinere eenheden binnen grotere organisatorische verbanden.

Ik zal in mijn betoog de volgende grote lijn aanhouden:

- eerst een globale bepaling van het onderwerp waarover we het hebben;

- vervolgens een tweetal achtergronden waardoor het autonomievraagstuk min of meer actueel is;

- daarna een aantal factoren die een rol spelen bij de succeskansen van autono. miseringsprocessen;

- en ten slotte een korte beschouwing van een aantal gevallen waarin ik meen dat deze factoren tot uitdrukking komen.

\section{Autonome groepen}

Als we willen spreken over autonome groepen, dan zullen we het er eerst over eens moeten zijn wat we daaronder zullen verstaan.

Laten we voor ons betoog afspreken dat we onder een groep verstaan:

- een samenstel van mensen (leden)

- met zekere gemeenschappelijke belangen

- met min of meer persoonlijke relaties (men kent elkaar ten minste van gezicht). De gemeenschappelijke belangen kunnen manifest of latent, sterk of nauwelijks be. wust zijn. Ze tekenen zich soms alléén af bij een verstoring van de gemeenschap. pelijke materiële of mentale omgeving. Ik spreek bewust niet van „gemeenschap. pelijk doel". Al te gemakkelijk wordt immers verondersteld dat zo'n doel dan wel een afgeleide zal zijn van „het” bedrijfsdoel of van „het” organisatiedoel. Dit is maar zelden en ook dan nog maar ten dele zo. Bovendien is het nog de vraag of er ooit één bedrijfs of organisatiedoel objectief valt vast te stellen.

Dat ik spreek van een samenstel wijst op ten minste énige duur en structuur.

Het kenmerk van de min of meer persoonlijke relaties, het elkaar tenminste van gezicht of van stem kennen, beperkt de omvang van de groep.

Een groep met een korte bestaansduur kan uiteraard niet veel méér dan een tiental personen omvatten. Groepen die jaren bestaan daarentegen kunnen een zeer grote omvang hebben, al zullen zich daarbinnen dan weer subgroepen vormen, waarbij ingewikkelde structuren kunnen ontstaan.

\footnotetext{
${ }^{1}$ Oratie uitgesproken ter gelegenheid van de aanvaarding van een buitengewoon lectoraat organisatiekunde aan de Universiteit van Amsterdam op 14 juni 1977.
} 
Zo kunnen mensen in een treincoupé gedurende een treinreis al een groep vor. men, maar ook de hele bevolking geboren en getogen in eenzelfde dorp of wijk. Meestal zal een groep een aanwijsbaar, beperkt fysisch territoir bezetten, al ma. ken moderne communicatiemiddelen dit niet altijd meer noodzakelijk.

De empirische basis van mijn betoog is voornamelijk ontleend aan onderzoek. en advieservaringen die ik opdeed in werk- of taakgroepen in arbeidsorganisaties, dat wil zeggen: groepen die een taak of takenpakket moeten uitvoeren, afgeleid uit de opgave waarvoor de gehéle organisatie, waarvan ze als groep deel uitmaken, is gesteld.

De omvang van deze groepen, afgezien van hun interne structurering en eventuele subgroepering, varieerde van zo'n tien tot honderd personen.

Deze empirische beperking tot werk of taakgroepen in arbeidsorganisaties betekent mijns inziens niet dat we er geen hypothesen uit mogen afleiden met be. trekking tot andere groepen binnen andere organisationele kaders. Bestuurskun. de en bedrijfskunde kunnen ook hier, naar mijn overtuiging, van elkaar leren.

Spreken over autonome werk- of taakgroepen (Herbst '68) in arbeidsorganisaties dwingt ons ook om een afspraak te maken over wat we met autonomie bedoelen. Onder autonomie wil ik in dit betoog verstaan:

- een toestand waarin de groep haar interne en externe interacties en communicaties op enigerlei wijze zonder tussenkomst van buitenaf stuurt en regelt.

Binnen een groep spelen zich tussen de leden allerlei uitwisselingsprocessen af. Men doet sommige dingen wèl of niét samen, men communiceert daarover, men doet dat op bepaalde manieren en met behulp van bepaalde middelen. Ook tussen de leden van de groep en de omgeving erbuiten bestaan uitwisselingsrelaties.

Deze interne en externe relaties vormen samen de interne en de externe structuur van de groep.

Zo'n groepsstructuur of netwerk van uitwisselingskansen nu wordt door twee bundels factoren bepaald:

- enerzijds door bij de leden levende richtinggevende of ook wel beperkende waarden, doeleinden, normen en verwachtingen,

- anderzijds door de buiten die leden voor de groep beschikbare materiële en technische middelen en mogelijkheden,

kortom door de cultuur en de technologie van de groep.

Om de vraag te beantwoorden in hoeverre een groep autonoom is, zullen we daarom moeten nagaan in hoeverre die groep haar eigen structuur kan bepalen of, met andere woorden, in hoeverre enerzijds de voor het groepshandelen rich. tinggevende en/of beperkende waarden, doeleinden, normen en verwachtingen uit de groep zèlf voortkomen, inplaats vanuit de omgeving te worden opgelegd, en anderzijds in hoeverre de groep kan beschikken over de facto eigen materiële en technische middelen. Het gaat dus om vragen naar de authenticiteit van de groepscultuur en naar de materiële identiteit van de groep.

Het zal duidelijk zijn dat er binnen elke organisationele context, dat wil zeggen binnen elk sociaal veld waarin zich doel-middel configuraties voordoen, en in het bijzonder binnen organisaties (waarin dergelijke doel-middel configuraties per definitie dominant zijn) nooit sprake kan zijn van méér dan een relatieve autonomie.

\section{Interne en externe autonomie}

Een belangrijke onderscheiding is in dit verband die tussen interne en externe autonomie. 
Interne autonomie valt bij kleinere, niet te complexe groepen meestal samen met wat systeemkundig kan worden aangeduid als

1. operationele autonomie

- de vrijheid om zelfstandig (dus zonder tussenkomst van buitenaf) de operaties binnen de groep (de produktiewerkzaamheden, het typewerk, de sportverrichtingen, of welke andere uitvoerende acties dan ook) te sturen en te rege. len.

Is de groep wèl complex, dan zou ik hiervan nog weer willen afzonderen de 2. coördinerende of structurerende autonomie

- de vrijheid om zelfstandig (dus zonder tussenkomst van buitenaf) binnen de groep de onderscheiden operaties door middel van allocatie, harmonisatie en assemblatie te combineren (bijvoorbeeld bij lay.out, routing, werkverdeling, plan. ning e.d.).

Ook hierbij zijn stuur. en regelprocessen aan de orde, zij het van een wat ho. ger niveau dan bij het eenvoudige operationele sturen en regelen.

Externe autonomie zou ik systeemkundig willen aanduiden als

3. transformationele (ook wel transactionele $\left.{ }^{2}\right)$ ) autonomie

- de vrijheid om zelfstandig (dus zonder tussenkomst van buitenaf) de transacties met de omgeving van de groep (bijvoorbeeld afspraken over de uit te voeren opgaven en daarbij geldende randvoorwaarden) te sturen en te regelen.

Het belang van deze onderscheidingen kan misschien al enigermate duidelijk worden, als men zich realiseert dat een bepaald doel, het realiseren van een met de omgeving overeengekomen transactie door het bewerkstelligen van een of an. dere transformatie aan een of andere materie, soms langs geheel verschillende wegen, met geheel verschillende middelen, of met andere woorden, via zeer uiteenlopende operationele alternatieven kan worden gerealiseerd.

Een paar voorbeelden: als de transformatie is het verzolen van een schoen, dan zijn operationele alternatieven: naaien, spijkeren of lijmen; als de transformatie is het vervoer van een postpakket, dan zijn operationele alternatieven wellicht: per auto, per trein, per vliegtuig of per schip. Er leiden vele wegen naar Rome.

Ook kunnen omgekeerd met één set operaties vaak meerdere transformaties worden bewerkstelligd. Niet alle wegen hoéven naar Rome te leiden.

Anders gezegd:

- het is zinvol onderscheid te maken tussen transformationeel programma en operationeel repertoire, ofwel tussen wat een eenheid voor de buitenwereld kan maken en wat z'n interne mogelijkheden zijn (Van der Zwaan '73, De Sitter c.s. '74).

Vooruitlopend op een volgend deel van mijn betoog wil ik hier reeds stellen dat, wanneer er tegenwoordig gesproken wordt over autonome groepen binnen organisaties, het meestal slechts gaat om een beperkte operationele en soms intern coördinerende autonomie maar zelden of nooit óók om transformationele autonomie.

Transactie impliceert ook specificatie van prijs, levertijd e.d. 


\section{Sturen en regelen}

Goed gereedschap is het halve werk en dat geldt in mijn ogen ook voor het we. tenschappelijk bedrijf.

Waar òns gereedschap voor een belangrijk deel bestaat uit een begrippenapparaat, ontkom ik er niet aan ook nog even stil te staan bij de termen sturen en regelen, die ik zopas heb ingevoerd. De onderscheiding is voor dit betoog misschien niet zo erg belangrijk, maar wèl wil ik in mijn totale werk proberen een consistente begripshantering vol te houden. Daarom toch even een toelichting: sturen verwijst naar vóórwaartskoppeling, regelen naar terúgkoppeling. Dat wil zeggen dat ook voor groepsautonomie, voor sturen en regelen dus, hoe ongeëxpliciteerd en primitief misschien ook, in enigerlei vorm stuur- en regelvoorzieningen nodig zijn, dat wil zeggen:

1. enigerlei soort beleidsvorming

2. uit een dergelijk beleid afgeleide normen of criteria

3a. in geval van sturing, sensoren waarmee dat wat ter transformatie binnenkomt wordt afgetast, gepeild of gemeten

3b. in geval van regeling, sensoren waarmee dat wat getransformeerd is af te tasten, te peilen of te meten is

4. in beide gevallen toetsingsmechanismen waarin de sensorinformatie wordt geconfronteerd met de normen (een monitorsysteem)

5. effectoren om in geval van afwijkingen van de normen de operaties of trans formaties te kunnen beïnvloeden.

Autonomie betekent voor mij dus hetzelfde als zelfmanagement:

- zelfstandig sturen en regelen gericht op onzekerheidsreductie.

Onzekerheid (uncertainty) hier op te vatten in de zin van: vraag die niet genegeerd of onbeantwoord kan blijven zonder „risico”, „onveiligheid” of „bedreiging" voor het systeem op te leveren. Sturen en regelen is noodzakelijk om te overleven, niet altijd in fysieke zin, maar wel om als groep identiteit te behouden.

De vraag is nu: waarom zou men dat willen, waar zou het goed voor zijn, dat vormen van groepen met een meer uitgesproken eigen karakter, met een sterker geprofileerde identiteit, kortweg van (meer) autonome groepen? Wat zijn de achtergronden van dit autonomiestreven? Ik meen dat we twee soorten achtergronden kunnen onderscheiden, waarin ook twee soorten motieven liggen besloten: een sociaal-structurele en een beheers-technische. Ik zal ze achtereenvolgens toelichten.

\section{Sociaal-structurele achtergrond}

Het lijkt me dat de sociaal-structurele hoofdlijnen als volgt zijn te schetsen.

Onze geïndustrialiseerde maatschappij wordt onder meer gekenmerkt door een zeer ver doorgevoerde rol- en arbeidsdeling, zowel op inter-individueel, op intergroeps als op inter-organisationeel niveau, vanaf dat van de kleinste leef-, produk tie- of bestuurseenheden tot dat van de grootste aggregaten zoals multinationals, statenblokken e.d.

Deze vèrgaande rol-en arbeidsdeling heeft een diepgaande specialisatie mogelijk gemaakt, waardoor op elk deelgebied een uitermate grote perfectie en efficiency mogelijk werden. Althans voorzover men erin slaagde tegemoet te komen aan de hoge eisen van coördinatie die ermee gepaard gingen, dat wil zeggen aan de 
noodzaak al die deelprodukties en dienstverleningen onderling op elkaar af te stemmen en weer in bruikbare combinaties bijeen te brengen.

Specialisatie en coördinatie sámen hebben in onze westerse samenleving tot een zeer hoog niveau van materiële welvaart geleid (overigens mede als gevolg van het secundaire effect: dat er ook een sterke machtspositie door is ontstaan ten opzich. te van de derde wereld), voor òns resulterend in een relatief zeer gunstige toestand van voeding, gezondheid, kennis, informatie, persoonlijke verplaatsings. mogelijkheden, beschikbare energie, vrije tijd enz.

Daar staat tegenover, dat het proces van specialisatie op al die maatschappe. lijke terreinen en niveaus geleid heeft tot een sterke zichtvermindering op het ge. héél. Meestal niet omdat men in absolute zin minder is gaan zien (wij zien waar. schijnlijk méér dan mensen vóór ons ooit gezien hebben) maar vooral omdat het gehéél zoveel omvangrijker, gedifferentieerder en complexer is geworden.

Ook voor coördinatie wordt een prijs betaald. Coördinatie betekent het afstaan van stuur. en regelbevoegdheden aan anderen, die verantwoordelijk worden voor het alloceren, harmoniseren en assembleren van de deelprodukties en deeldien. sten. Coördinatie is altijd tot op zekere hoogte coördinatie door anderen, dat wil zeggen ze impliceert heteronomie. Deze heteronomie heeft in ònze maatschappij dan ook nog een specifiek karakter: ze is vrijwel overal op een of andere manier gerelateerd aan de typisch kapitalistische scheiding van arbeid en middelen.

Zichtbeperking en heteronomie tezamen nu, leveren het verschijnselencomplex op dat we aanduiden met het begrip verureemding: een werk-, woon-, levens- of we. reldsituatie, die nog slechts zeer ten dele als ,eigen” herkend wordt (Schacht '72, v. Strien c.s. '75). Over de objectieve en subjectieve aspecten ervan zal ik hier niet méér opmerken dan dat daarbij de subjectieve verureemding toeneemt naarmate het materiële welvaren toeneemt.

Van belang is, dat er zich een merkwaardig spanningsveld voordoet tussen dat hoge materiële welvaartsniveau, met al zijn schijnbare mogelijkheden en potenties aan de ene kant, en die sterke vervreemding, het zich onmachtig en niet thuis voelen aan de andere kant.

Deze situatie is principieel onaanvaardbaar en onverdragelijk en we zien dan ook een rijke schakering aan pogingen van de mensen om eraan te ontkomen zoals:

- non-participatie, d.w.z. gewoon afhaken, niet meer meedoen, je echt of gesimuleerd ziek melden (was kort na de oorlog een ziektepercentage van $5 \%$ al hoog, $\mathrm{nu}$ is $10 \%$ vrij gewoon), op de duur meestal in combinatie met een specifieke vorm van

- escapisme, d.w.z. de vlucht in een of ander min of meer fanatiek bedreven tijdverdrijf, in een of ander sektarisch geloof, in occulte praktijken e.d., soms in alcohol of in andere drugs;

- criminaliteit, d.w.z. het meer of minder agressief demonstreren van het je nietverbonden en niet-verantwoordelijk voelen, door je te vergrijpen aan dingen of mensen (denk aan het vernielen van treinen bij voetbalevenementen e.d.), of in

- veranderingsactivisme, d.w.z. felle politieke activiteit, direct gericht op het opheffen van al dan niet vermeende oorzaken van de onaanvaardbare toestand (Kas. telein '75). 


\section{Methoden tot vervreemdingsreductie}

Voor het reduceren van de hiervoor omschreven spanningen in arbeidsorgani. saties worden verschillende mogelijkheden beproefd, afzonderlijk en in combinatie, en het streven naar groepsautonomie wil ik in dit vlak zien.

De meest radicale mogelijkheid, het zonder meer terugdraaien van het specialisatie-coördinatiecomplex, komt daarbij niet in aanmerking, omdat men van de daaruit resulterende materiële welvaart geen afstand wil doen.

1. Een van de minst ingrijpende methoden is het terugdringen van de zichtbe. perking, door het geven van aanvullende informatie over het geheel. Dit kan op zichzelf weer variëren van het incidenteel verstrekken van eenvoudige voorlichting tot het permanent en systematisch aanbieden van overzicht. en inzichtvormende programma's.

Ik heb met vrijwel alle vormen van technische, economische en sociale zichtverruiming in gedraineerde werksituaties nogal intensief te maken gehad en mijn stellige indruk is dat, hoewel de mogelijkheid tot zichtverruiming door informatieverstrekking in principe nooit ongebruikt mag blijven, ze op zich. zelf ontoereikend is. Dit komt omdat ze, naast het geven van de voldoening van méér te zien en te begrijpen, de heteronomie niet terugbrengt, maar integendeel weer nieuwe frustraties oproept door verhoging van het heteronomiebesef.

2. Een tweede, veel ingrijpender, methode is die van een of andere vorm van dé-specialisatie, bijvoorbeeld door

a. periodieke individuele werk- of taakwisseling (job rotation), of door

b. permanente werk- of taakverrijking (job enrichment) d.w.z. het horizontaal of vertikaal uitbreiden van de individuele taak met elementen die de operatiecyclus verlengen en waardoor er bijvoorbeeld voorbereiding en/of controle binnen vallen e.d.

c. het verst gaat men hierin, wanneer men een groep als gehéél, en niet één. malig maar continu, de gelegenheid geeft de te verrichten individuele taken af te leiden uit, en onderling te verdelen en te structureren rònd een min of meer compleet produkt of een complete dienst, en dan spreken we over werkof taakstructurering.

Hierbij komt in de meest geavanceerde gevallen ook de technologie ter dis. cussie: bijvoorbeeld al of niet een lopende band, welke ruimtelijke opstelling van de machinerieën, welke keuze van gereedschappen en hulpmiddelen, hoe de routing van de stukken enz.

3. Dit laatstgenoemde permanente taakoptimaliseringsproces is nauwelijks of niet denkbaar zonder intensief werkoverleg, een derde methode, die dan ook dikwijls in één adem met werkstructurering wordt genoemd. Werkoverleg komt echter ook voor zònder werkstructurering in de hierbovengenoemde zin van:

permanent intern groepsstructurerend proces.

Mijn indruk is ook in dit geval weer, dat werkoverleg zonder een daarop aansluitend vrij proces van werkstructurering op de duur een frustrerende zaak is. Werkoverleg en werkstructurering zie ik als onlosmakelijk aan elkaar verbonden. Bovendien: zonder toereikende, het individuele werkzicht overschrijdende, informatie is dit overleg niet mogelijk. Ook zichtverruiming door informatieverstrekking is dus een voorwaarde. 
Alle drie sámen, informatie, overleg en permanente taakstructurering, resul. teren in, wat ik eerder noemde, een vorm van interne groepsautonomie.

Binnen de groep worden dan de individuele taken gecoördineerd op basis van informatie en overleg, waarin alle betrokkenen hebben kunnen participeren. Dit behoeft niet per se een formeel democratische besluitvorming te betekenen volgens het one-man-one-vote systeem. Het kan soms beperkt blijven tot groepsconsultaties door de groepsleider, die daarna zèlf zijn beslissingen neemt. Criterium is dat deze beslissingen over de interne gang van zaken niet van buiten de groep ingegeven worden en dat in principe alle groepsleden invloed kunnen uitoefenen.

Wanneer is er nu ook sprake van externe groepsautonomie? Deze, betrekkelijk zeldzame, situatie doet zich voor bij vrije contractering tussen groep en omgeving, dat is in de meeste gevallen dus de overkoepelende organisatie. Externe groepsautonomie betekent immers:

- dat de groep vrij onderhandelt over al dan niet te accepteren opgaven en randvoorwaarden.

In het bouwbedrijf komt deze situatie nogal eens voor. Een autonoom onder. aannemende ploeg is daar vaak net zo groot als er personen in een volkswagenbus kunnen. Bij de heiers was er tot voor kort (ik weet niet of het nu nòg zo is) bovendien nog sprake van een sterke democratische traditie met betrekking tot het interne sturen en regelen. Nog niet zo heel lang geleden hadden sommige bedrijven in de Zaanstreek (ik spreek uit een beperkte eigen ervaring - misschien was dit elders ook wel zo) min of meer extern-autonome laad- en losploegen.

Waarschijnlijk echter moeten we dergelijke voorbeelden eerder zien als schaarse, hardnekkige resten uit een onomkeerbaar ambachtelijk arbeidsverleden, dan als steunpunten voor een nieuw begin.

Vooral het ook extern autonoom maken van werk- of taakgroepen, die een integrerend deel uitmaken van moderne complexe organisaties, vergt geheel nieuwe stuur- en regelvoorzieningen en spelregels: voorzieningen voor monitoring en arbitrage. Zelfs als het alleen maar gaat om interne autonomisering zijn dergelijke voorzieningen al vereist, zeker ingeval van wat omvangrijker of complexer taak. pakketten.

Om dit toe te lichten is het nodig nu eerst de beheers-technische achtergrond van het autonomiseringsstreven eens te bezien.

\section{Beheers-technische achtergrond}

Het nog altijd dominante en vroeger zo succesvolle beheersmodel waardoor organisaties, zowel in de publieke als in de private sfeer, in onze moderne westerse samenleving worden gekenmerkt, is dat van wat ik elders heb genoemd: de centrale aspectspecificatie (Kastelein '72, '73). Wèl is er langzamerhand in vergelijking tot dat model heel wat verval waar te nemen: nergens durft of kan men het meer consequent toepassen. Kort gezegd komt centrale aspectspecificatie neer op:

- een vorm van beheersing van de operaties door middel van gedetailleerd specificerende instructies, voorschriften, regelingen e.d. en van daarop aansluitende terugkoppelinformatie, vàn en náár een centrum;

- een centrum waarin per aspect van de operaties een zo groot mogelijke deskundigheid is geconcentreerd, zoals het personeelsaspect, het kostenaspect, het materieelaspect, het werkmethode-aspect, het onderhoudsaspect, het plannings-aspect, enz., elk eventueel nog weer opgedeeld in vele deelaspecten. 
De aspectspecialisten trachten daarbij zoveel mogelijk te vóórzien wat er in de operationele sfeer kan vóórkomen en ze zoeken hierbij van te voren de best mo. gelijke standaardoplossing, the one best way. Gebeurt er toch iets onvoorziens, dan moeten ze, als het enigszins mogelijk is, alsnog worden ingeschakeld en in elk geval moet aan hen worden gerapporteerd.

Of een dergelijke organisatie qua formele bevoegdheidsverdeling aangemerkt wordt als een functionele organisatie (dan hebben de aspectspecialisten een di recte orderbevoegdheid) of als een lijn-staf organisatie (waarbij de aspectspecialisten formeel via de met commandobevoegdheid beklede lijnfunctionarissen opereren) is naar ik in de praktijk heb geleerd, niet zo belangrijk.

Centrale aspectspecificatie heeft, naast de vervreemdingsgevolgen, die we bij de sociaal-structurele achtergronden van het autonomiseringsstreven al hebben aangegeven (centrale aspectspecificatie is immers niet anders dan een specifieke en zeer pregnante vorm van het specialisatie-coördinatie complex), het beheerstechnische bezwaar dat ze moeilijker wordt naarmate er meer sprake is van toename van:

1. de schaal van de te beheersen gebieden, binnen en/of buiten de organisatie, zoals de organisatie-omvang en de omvang van relevante markten;

2. de diversiteit of gevarieerdheid binnen de te beheersen gebieden in en/of buiten de organisatie, dat wil zeggen het aantal daarin te onderscheiden relevan. te variabelen;

3. de dynamiek binnen de te beheersen gebieden, ook weer intern en/of extern, dat wil zeggen de mate van wisseling van de te beheersen variabelen en de snelheid en breedte van de variaties;

4. de verwevenheid van de te beheersen gebieden, intern en/of extern, anders ge. zegd: de complexiteit, interdependentie of onderlinge afhankelijkheid van de variabelen.

De aspectbetrokken specificaties immers, de voorschriften en regels, zullen ook moeten toenemen en vaker gewijzigd moeten worden.

Veel van de consequenties ervan zullen vanuit het centrum niet goed kunnen worden voorzien. Bovendien: alle aspectspecificaties tezamen moeten een sluitend, althans een niet-intern-strijdig geheel vormen: ze hebben betrekking op een in de meeste opzichten niet deelbare werkelijkheid.

Elke wijziging bedreigt daarom het systeem van voorschriften en regels als ge. héél, roept dus enorme coördinatieproblemen op en geeft aanleiding tot een voort. durend weer óverbelast worden van de centrale stuur. en regelorganen.

Centrale aspectspecificatie onder condities van toenemende schaal, diversiteit, dynamiek en verwevenheid leidt derhalve onvermijdelijk tot starheid en reductionisme. Met dit laatste bedoel $\mathrm{ik}$, dat de beheersing plaatsvindt op basis van veel te sterk versimpelde modellen van de werkelijkheid, waardoor hoe langer hoe meer essentiële variabelen genegeerd worden. Zeer grote moeilijkheden ontstaan na. tuurlijk als een dergelijk systeem dan óók nog geconfronteerd wordt met toena. me van:

5. de mondigheid van de participanten, de klanten of van betrokken derden (een bijzondere vorm van toename van diversiteit en dynamiek).

Mensen en groepen eisen ruimte voor identiteit en die is per definitie centraal onvóórzienbaar.

Het zal duidelijk zijn dat een dergelijk beheerssysteem op den duur dus zowel 
om z'n sociale en psychologische effecten, als om z'n beheers-technische merites in engere zin (bij toenemende schaal, gevarieerdheid, dynamiek en verweven. heid) onhoudbaar wordt. De centrale aspect-specialisten voegen dan geen waarde meer toe aan de primaire processen aan de basis van de organisatie, maar nog slechts kosten. Ik wil hier erop wijzen dat dit beheerssysteem niet alleen kenmerkend is voor grote complexe organisaties in de private sfeer, maar ook voor die in de publieke sfeer. Bij organisaties in de publieke sfeer speelt ter rechtvaardiging van dit stelsel, naast het beginsel van economische standaardisatie, ook nog dat van de rechtsgelijkheid. Dat maakt ze vaak moeilijker veranderbaar.

\section{Beheers-technische mogelijkheden}

Het alternatief is: een strikte beperking van het centrale transformationele sturen en regelen tot voor het omvattende geheel vitale hoofdzaken en een hoge mate van vrijgeven van het operationele sturen en regelen aan de subsystemen.

Hiervoor zijn echter andere beheerssystemen nodig (Naschold '70). Het over koepelende centrale stuur. en regelsysteem zal moeten beschikken over globale normen, kengetallen, budgetgrootheden e.d. waaraan het de input-output verhoudingen van de subsystemen kan toetsen. Met de throughput van deze systemen heeft het alleen bemoeienis als en in zoverre deze, niet incidenteel maar structureel, niet in staat blijken aan de transformationele minimumeisen te voldoen. De subsystemen zelf moeten eveneens beschikken over normen, maar nu om hun operaties naar eigen inzicht te kunnen sturen en regelen om tot een zo gunstig mogelijk totaalresultaat te komen.

De informatie-technische mogelijkheden voor het snel en doeltreffend verzamelen, verwerken, distribueren en presenteren van de hiervoor benodigde gegevens zijn in onze samenleving potentieel ruim aanwezig (Kastelein '70).

Ook de menselijke mogelijkheden en behoeften om zelfstandig informatie te verwerken en er constructief op te reageren aan wat nu nog vaak wordt genoemd „de voet van de pyramide" of de „basis”, is de laatste decennia enorm toegenomen (Kastelein '70).

\section{Cumulatie van sociaal-structureel en beheers-technisch motief}

Waar het sociale motief, reductie van de spanningen die het gevolg zijn van de wanverhouding tussen vervreemding en materiële welvaart, zich meestal het eerst láger in de organisaties manifesteert, tekent het beheers-technisch motief zich doorgaans het eerst af bóven, of liever centraal, in de organisatie. In het laatste geval spreekt men niet over autonomisering van groepen maar over divisievorming, decentralisatie e.d.

Beide motieven, mits betrokken op de gehéle organisatie en niet het één voor. namelijk op de top en het ándere vooral op de basis, steunen elkaar. Ik heb dan ook sterk de indruk, dat in de praktijk pogingen tot het realiseren van een méér of minder vèrgaande groepsautonomie aan de basis pas een goede kans maken als men aan de top het beheers-technische échèc van de centrale aspectspecificatie begint te doorzien. Het zou interessant zijn dit nader te onderzoeken.

Hiermee zijn we gekomen bij het vraagstuk van de factoren die de kansen op het welslagen van groepsautonomisering beïnvloeden, die voor een deel zelfs succesvóórwaarden zijn. 
In de eerder gegeven omschrijving van wat groepsautonomie omvat, kwam al naar voren dat ze een zekere stuur-en regelbewerktuiging van zo'n groep impliceert. Deze bewerktuiging is meestal in de uitgangssituatie, vóór het begin van het autonomiseringsproces, niet zonder meer, of niet in passende vorm, gegeven.

Zo zal er, zoals al is opgemerkt, een voor de leden duidelijk beleid moeten komen, waaruit hanteerbare èn acceptabele operationele normen kunnen worden afgeleid. Er zullen aan de input- en aan de outputzijde van het groepsproces redelijk betrouwbare signalerende meetpunten, sensoren moeten zijn of moeten worden geïnstalleerd. Variaties moeten tijdig aan de normen kunnen worden getoetst en de daaruit voortvloeiende stuur. en regelbeslissingen moeten ook daadwerkelijk kunnen worden geëffectueerd. Kortom: heel het bekende lijstje met cybernetische checkpoints moet worden afgewerkt en er moet een "dashboard" worden geconstrueerd. Elders heb ik de te volgen procedure vrij uitvoerig beschreven en ik zal er dan ook nu niet dieper op ingaan (Kastelein '73).

\section{Geinstitutionaliseerd overleg}

Is een dergelijk dashboard, of monitorsysteem zoals ik dat graag noem, beschikbaar, dan zal het ook gebruikt moeten worden door de groep, in die zin, dat in principe alle leden er - in combinatie met eigen directe waarnemingen - stuur- en regelconclusies uit moeten kunnen afleiden en deze in de besluitvorming moeten kunnen inbrengen. Groepsautonomie impliceert namelijk participatie van de leden in het besluitvormingsproces. Zou alléén de leider de koers vaststellen, het dashboard aflezen en op grond daarvan sturen en regelen, dan is er immers geen sprake van groepsautonomie maar van individuele autonomie van de chef. Dit laatste kan een stap in de richting zijn, maar het is nog lang geen groepsautonomie.

Ook de vorm van het groepsbesluitvormingsproces moet niet te zeer van buitenaf gespecificeerd worden. In de ene situatie zal een groepsconsultatie door de chef, die uiteindelijk zelf beslist, passend zijn, in de andere zullen wellicht meer parlementaire procedures wenselijk en mogelijk zijn. Er zijn nog allerlei andere modellen denkbaar. Ook op dit punt zal de interne groepsstructuur consistent moeten zijn met de structuur van de opgaven waarvoor de groep gesteld wordt (Cohen '69). Belangrijk is dat het overleg qua vormgeving een redelijk uitgekris. talliseerd, onomstotelijk vaststaand, regelmatig terugkerend en legitiem gebeuren is.

Hiervoor is een leerproces (Mulder '72, '77) vereist, dat overigens naar mijn inzicht minder in de sensitivity-sfeer behoort te liggen, dan in die van het aanleren van een aantal elementaire instrumentele vaardigheden op het gebied van vergadertechniek en het vastleggen, lezen en interpreteren van zakelijke informatie.

Het groepsoverleg moet namelijk plaatsvinden naar aanleiding van de door het monitorsysteem, op het dashboard, gepresenteerde kosten - baten informatie e.d. en moet uitmonden in practische conclusies. Dit betekent niet dat er geen ruimte mag blijven voor open beeldvorming en voor meer emotionele sociale en psy. chologische processen, maar die mogen niet gaan overheersen en doel in zichzelf worden. In dit opzicht zie ik met een zekere zorg allerlei non-directieve organisatie-ontwikkelingsactiviteiten, of pleidooien ervoor, aan. 


\section{Twee soorten betrokkenheid}

Als een passend monitorsysteem èn een regelmatige overlegmogelijkheid over de eruit af te lezen informatie zijn gerealiseerd, dan is het tòch nog de vraag of de leden ook daadwerkelijk zullen participeren en in welke mate. Dit is afhankelijk van hun motivatie, met andere woorden van de vraag of ze er enig moreel of materieel belang bij hebben of aan hechten.

In dit verband is het goed om vast te stellen dat de arbeidsbetrokkenheid van organisatieleden varieert van zeer partieel en extrinsiek tot totaal en intrinsiek.

1. Bij de partiële, extrinsieke betrokkenheid wordt nauwelijks zelfverwerkelijking in het werk gezocht. Deze wordt vooral elders, buiten het werk, nagestreefd.

Het gaat hier voornamelijk om de knikkers, nauwelijks om het spel.

Te denken is in dit verband aan korte, part time jobs die vaak via uitzendbu reaus worden bemand (Van Haasteren en Van Overeem '76).

2. Bij de totale, intrinsieke betrokkenheid wordt zelfverwerkelijking in hoge mate in het werk gezocht. Men is ,getrouwd" met het werk.

Het gaat hier voornamelijk om het spel en de knikkers worden vanuit dát perspectief gezien.

Nu kan het uiteraard zijn, dat geringe intrinsieke arbeidsbetrokkenheid een ge volg is van zichtverlies en heteronomie, een vorm van afhaken dus, die men juist door autonomisering van de groep weer kan proberen terug te dringen. Ik meen echter, dat er zich inderdaad óók talrijke situaties voordoen, waarin autonomise. ring zeer moeilijk zo niet onmogelijk is, als gevolg van al tè ver voortgeschreden vervreemding. Hoge verwachtingen met betrekking tot zelfverwerkelijking in, of het ontlenen. van welke waarden dan ook áán het werk, ánders dan een zeker inkomen en redelijk comfortabele arbeidsomstandigheden, bestaan dan niet meer. Ook het wekken van dergelijke verwachtingen en ambities stuit dan op sterke weerstanden, omdat de consequenties zouden zijn, dat men z'n inmiddels elders gebonden aandacht en energie weer meer op de werksituatie zou moeten richten. Dit wordt dan gevoeld als een vrijheidsbeperking, een beperking van de individuele ontplooiingsmogelijkheden.

Het ligt voor de hand, dat naarmate de betrokkenheid groter is, doorgaans ook de autonomiseringsbehoeften en ook de menselijke mogelijkheden groter zijn. (Zie ook Hendriks '74)

\section{Invloedspakket en invloedsverdeling}

Autonomisering maakt de betrokken groepen minder afhankelijk, geeft ze meer invloed op eigen werk en werkomstandigheden.

Daartegen bestaat echter, zowel bij wat men wel aanduidt als het management in de bedrijven en andere instellingen, als bij tal van bestuurders van de vakorganisaties, nogal wat wantrouwen en verzet. Dit is dunkt me gebaseerd op geloof in zo-iets als een ,wet van behoud van invloed". Het zou hierop neerkomen: als je in een organisatie de invloed van een bepaalde categorie op de gang van zaken laat toenemen, dan zal ergens anders in die organisatie de uitgeoefende invloed evenredig afnemen:

- het management vreest door werkelijk houtsnijdend werkoverleg verlies van invloed op het bedrijfsgebeuren; 
- de vakorganisaties vrezen door werkoverleg aan de basis uitholling van het meer centraal georganiseerde overleg.

Er moet echter onderscheid gemaakt worden tussen

- het totale pakket van in een organisatie op het gebeuren uitgeoefende invloed en

- de verdeling over de verschillende hiërarchische niveaus in de organisatie van de uitgeoefende invloed (Lammers '65).

Het kan zijn dat topmanagement en/of vakbondsbestuurders relatief een zeer grote invloed uitoefenen, maar dat ze - in vergelijking tot wat wenselijk en mogelijk is - toch maar een zwakke greep hebben op wat er gebeurt. Omgekeerd kan men zich een situatie denken met minder pregnante invloedsverschillen tussen top en basis, maar met netto een grotere greep van alle betrokkenen sámen op het totaal van het te beheersen gebeuren.

Autonomisering kan er dikwijls toe bijdragen een naar hiërarchisch échêlon betrekkelijk steil oplopende, maar zich gemiddeld op een laag niveau bewegende, invloedslijn te kantelen tot een wat vlakkere lijn op een wat hoger niveau. Met i'n allen beheerst men de situatie dan wat beter dan vroeger.

Alleen als management en vakorganisaties dit inzien of aanvoelen zullen ze werkelijk bereid zijn om méér dan vrijblijvende verbale steun te geven aan au. tonomiseringsprojecten.

\section{Succesvoorwaarden voor autonomisering}

Op grond van het vóórgaande, en daarin zijn dus zowel eigen ervaringen en onderzoek als indrukken uit de literatuur verwerkt, kom ik nu tot een aantal voorwaarden, waaraan - lijkt mij - moet worden voldaan om autonomisering op groepsniveau kans op succes te geven, of op z'n minst tot een aantal factoren die de succeskansen aanzienlijk bevorderen.

Ik moet bekennen dat ik er daarbij niet geheel aan ben ontkomen enkele van die voorwaarden of factoren enigermate tautologisch te laten klinken. Zo van: autonomie lukt als het ook werkelijk autonomie is. De oorzaak is, dat er in de organisatiepraktijk heel wat ogenschijnlijke autonomiseringsprojecten zijn, die bij nadere beschouwing blijken in feite weinig of geen autonomie te kunnen en te mógen opleveren.

Het is van belang er nota van te nemen, dat het naar mijn idee niet altijd nood. zakelijk is dat âlle voorwaarden tevoren al vervuld zijn, of dat alle factoren reeds aanwezig zijn, op het moment van starten van een autonomiseringsproject. Ze kunnen ook tijdens en dóór het project zelf tot realisering komen.

Deze succesvoorwaarden of factoren nu zijn:

1. de belangrijke machtscentra in de omgeving van de groep (management, vaak ook vakorganisaties) moeten er enigerlei voordeel in zien (materieel of moreel) (vgl. Leemans '76);

2. de groep zelf moet enigerlei belang hechten aan of krijgen bij een grotere autonomie (materieel of moreel);

3. de transformationele eisen waaraan de groep moet voldoen, moeten goed vertaalbaar zijn of worden in door beide partijen (groep en omgeving) herkenbare en erkenbare grootheden (taaknormen, taakcondities, meetpunten); 
4. er moet, gebruik makende hiervan, een monitorsysteem kunnen worden geconstrueerd voor

- tweezijdige bewaking van het contract

- fundering van stuur- en regelbeslissingen;

5. in principe de gehele groep moet op basis van informatie uit bovengenoemd monitorsysteem, aangevuld met informatie uit eigen waarnemingen, regelmatige kunnen overleggen over werk, werkresultaten en werkomstandigheden;

6. dit overleg moet kunnen leiden tot reële en door de groep als betekenisvol gevoelde stuur- en regelbeslissingen met betrekking tot hun werk en werkomstandighe. den (bevoegdheden).

Over dit laatste punt nogmaals: het is dus niet noodzakelijk dat er een soort parlementair democratische procedure wordt gevolgd. Integendeel: hoe informeler het, op zich formeel gelegaliseerde en naar plaats en tijd ook geïnstitutionaliseer. de, overleg verloopt, hoe vruchtbaarder het meestal zal zijn. De groepsleider kan dan wel degelijk een manager zijn die, gehoord zijn mensen en binnen het kader van het groepsbeleid, zelf snel en doeltreffend beslist.

Wèl is het van belang dat de groep scherp leert onderscheiden:

- situaties waarin ze moet functioneren als „raad” d.w.z. waarin ze van binnenuit en van beneden af verantwoordelijkheden aan de groepsleider toedeelt èn

- situaties waarin ze moet functioneren als „operationele eenheid" d.w.z. waarin ze van buiten af en van bovenaf via de groepsleider verantwoordelijkheden krijgt toegedeeld. Dit onderscheid blijkt met name aan universiteiten, waar velen slechts raden-ervaring hebben, nogal eens moeilijk te vallen. (Tarschys, '77).

Ik wil hieronder nu een drietal gevallen, waarbij ik zelf betrokken ben geweest of nog ben, aan de hand van de bovengenoemde zes punten kort proberen te eva. lueren en daarna aan de hand van hetzelfde lijstje enige indrukken geven over de situatie, zoals die zich elders voordoet.

\section{Het T- en D-project in de telefoonbultendienst bij PTT}

Ik heb het project elders beschreven. Het ging erom de uitvoerende eenheden, belast met het aanleggen en onderhouden van lokale kabelnetten, telefoonaan. sluitingen en huisnetten en -installaties, meer tot "self-managing units" te maken. Er waren en zijn pakweg zo'n 130 van dergelijke lokaal gesitueerde „dienstkringen”, elk van zeg om en nabij een 25 tot 75 man sterk. De uitgangstoestand werd gekenmerkt door een hoge mate van centrale aspectspecificatie vanuit centra in de telefoondistricten en vanuit de Centrale Directie van PTT te 's.Gravenhage. In een klein aantal „proefdienstkringen” werd geprobeerd een nieuw, op de groepsautonomie-idee gebaseerd systeem van taakstelling, resultatencontrole en participatieve sturing en regeling, kortweg T. en D-systeem (van Taakstelling en Deelneming), van de grond te krijgen.

Wat betreft de cruciale factoren:

1. het eind van de 60'er jaren gaf een hoogconjunctuur van participatie- en de. mocratiseringsideologieën te zien en ook de PTT.leiding was zich ervan bewust dat er iets moest worden gedaan.

Bovendien rezen er in de volksvertegenwoordiging vragen m.b.t. de doelma. tigheid van het PTT.bedrijf, die aanleiding waren tot onderzoeken door ex. terne organisatie-adviesbureaus. In dit klimaat leek het taakstellings- en deel. 
nemingsproject tegemoet te komen aan de noodzaak om zowel de produk tiviteit als de participatie te bevorderen. De top stond waarschijnlijk op deze gronden in het algemeen vrij positief tegenover het project. De ideologische conjunctuur in de omringende maatschappij is inmiddels echter omgeslagen en ook de manifeste externe produktiviteitsdruk is goeddeels weggevallen.

Het middenkader daarentegen was, en is nog steeds, overwegend wan trouwend: het vreest voor positie- en perspectiefuitholling. De bedrijfsleiding heeft uiteindelijk niet frontaal door deze weerstand willen heenbreken.

Daarbij kwam dat de vakorganisaties zich zeer gereserveerd op de achter. grond hielden. Op een kritiek moment eisten ze echter zeer duidelijk de categorische garantie, dat in het werkoverleg nooit zaken aan de orde zouden komen die ook onderwerp zouden kunnen zijn voor het georganiseerd over. leg. Een dergelijke eis is aan de basis uiteraard nauwelijks te operationaliseren.

2. De betrokken groepen kregen geen materieel belang bij een goed autonoom functioneren en bleken slechts een betrekkelijk groot moreel belang te hech. ten aan de te verwerven grotere autonomie.

Dit bleek uit het uitblijven van verzet of openlijk protest toen het betrekkelijk geringe wat na jaren experimenteren in de "proeftuinen" toch verworven werd, weer werd teruggedraaid.

Hoewel dit niet ligt aan een lage graad van arbeidsbetrokkenheid, was een belangrijke factor waarschijnlijk wèl de ruime uitwijkmogelijkheden met de grijze dienstauto'tjes in het technische werk buiten de poorten van het bedrijf.

3. Met grote inzet en vernuft werden door arbeidsanalisten en andere specia. listen, in samenspraak met de direct betrokkenen, voor zeer uiteenlopende werkzaamheden en werkcondities redelijk bruikbare normen en correctiefactoren vastgesteld en beproefd.

4. Er werd een verslaggevingssysteem ontwikkeld dat in vergelijking tot het be staande systeem redelijk snel, gedetailleerd en betrouwbaar de belangrijkste informatie over het reilen en zeilen van de eenheden weergaf. Per kwartaal werd per eenheid een totaal ,winst”. of „verlies"-cijfer geproduceerd, onderbouwd door meer gedetailleerde gegevens. In enkele proeftuinen heeft dit systeem bijna 2 jaar zó bevredigend gedraaid, dat het betreffende district het ook wilde invoeren voor de overige eigen dienstkringen.

5. In de „proeftuinen” vond wel regelmatig, en vaak zeer geanimeerd, werk overleg plaats, mede op basis van de uit bovengenoemd monitorsysteem ver. kregen bedrijfsinformatie.

6 Het omringende organisatiesysteem stond echter naar het oordeel van de be. trokkenen geen stuur-en regelbevoegdheden van betekenis af aan de eenhe. den.

N.B. Een extra complicatie was, dat wat in een klein aantal dienstkringen ge durende \pm 7 jaar werd ontwikkeld, formeel pas ná de proefperiode aan de rest van het bedrijf mocht worden gepresenteerd.

De tam-tam had in die jaren echter, sneller dan de telefoon, al zoveel onheil. spellende geruchten over het in de maak zijnde systeem rondgetrommeld, dat tóén tegen de vooroordelen niet meer opgetornd kon worden.

Slechts een beperkt aantal, sterk aangepaste en vooral administratieve elemen. ten van het $T$. en D-systeem zijn tenslotte geaccepteerd en worden nu geleidelijk aan landelijk ingevoerd (Kastelein '74). 


\section{De Centrale Afdeling Organisatie bij PTT}

Mijn eigen organisatie-afdeling bij PTT, op het ogenblik een kleine 25 koppen groot, was vrij intensief bij het hierboven genoemde project betrokken. Meer en meer ontstond het gevoel dat we de T. en D-filosofie ook voor de eigen afdeling zouden moeten laten gelden.

Kansen om op dit terrein iets verder te komen deden zich voor, toen de on derafdeling automatisering afgescheiden werd en opgenomen werd in een nieuw gevormd directoraat. Inplaats van de starre, harksgewijze indeling in - naar functioneel werkgebied geformeerde - burelen (werkmethoden, structuur en automatisering), elk onder leiding van een vaste bureelchef, werd er een flexibele projectenorganisatie opgezet, met periodiek opnieuw te kiezen groepsleiders, die samen met het hoofd de afdelingsraad vormden.

Met betrekking tot de interne werkstructuur werd hiermee een grote mate van autonomie bereikt.

Voorts werden budgetten verworven voor de permanente opleiding, vorming en training van de medewerkers, binnen een algemeen beleidskader naar eigen inzicht van medewerkers en afdeling zelf te besteden. Grotere invloed werd voorts verkregen op de samenstelling van het werkpakket en op de spelregels waaronder dit uitgevoerd zou worden. Het afdelingsbeleid zou jaarlijks in de „,constituerende" afdelingsvergadering worden besproken.

1. De top stond aanvankelijk nogal gereserveerd tegenover deze nieuwlichterij. Het eigen kader binnen de afdeling was overwegend positief. De houding van de vakorganisaties was nauwelijks relevant. Ze hebben deze verandering, die op zulk een kleine schaal plaatsvond, waarschijnlijk niet eens opgemerkt.

2. Het personeel had geen materieel belang bij verandering. Er is zelfs wel eens gesuggereerd dat men zichzelf in de vingers zou snijden, omdat door het weg. vallen van de bureelchefsfunctie er minder promotiekansen zouden zijn. De groepleiderspositie wordt buiten de afdeling formeel namelijk niet erkend en geeft geen recht op een hogere rang of salariëring.

Het personeel hechtte en hecht daarentegen een groot moreel belang aan de autonomie, maar is ook vaak teleurgesteld in het resultaat. Klaarblijkelijk zijn tal van verwachtingen nog gefrustreerd. Niemand zou echter terug willen naar de oude situatie.

3. In aanmerking genomen de vele niet gemakkelijk kwantificeerbare aspecten in het organisatiewerk, is er een redelijk bruikbaar pakket aan ervaringsnormen beschikbaar.

4. Er is een in principe voor dit soort werk zeer goed beheersinformatiesysteem ontwikkeld, dat echter in het stuur-en regelproces nog onvoldoende wordt gebruikt.

5. Er is regelmatig werkoverleg in diverse verbanden (projectgroepen, sociale basisgroepen, afdelingsraad, afdelingsjaarvergadering, ad hoc hearings).

6. De afdeling heeft intern vrij grote stuur- en regelmogelijkheden en potentieel een vrij grote invloed op de externe werkrelaties.

N.B. Een complicatie is de onbevredigende positie van de afdeling in de topstructuur van PTT, die weinig of niet vanuit de afdeling beïnvloedbaar is en de onzekere situatie in verband met de voorgenomen spreiding van PTT-diensten.

Naar mijn oordeel mag hier toch van een geslaagde verandering in de richting van zowel intern als extern zelf-management worden gesproken. 


\section{Vakgroep V aan de FSW-a}

Ik kan niet nalaten om de checklist ook toe te passen op mijn vakgroep hier aan de universiteit ${ }^{3}$ ), omdat ik ervan uitga dat met de instelling van de vakgroepen beoogd werd autonome basiseenheden voor het universitaire bedrijf te vormen (WUB). Mijn indrukken zijn als volgt samen te vatten:

1. De belangrijkste omgevingssystemen, de politieke zowel als de bureaucratische, op subfaculteits-, faculteits-, universitair en departementaal niveau, geven met hun overvloed aan richtlijnen, voorschriften, bepalingen en veto's allerminst aanwijzingen dat men ook de facto veel op heeft met de autonomie van vakgroepen. Integendeel: in toenemende mate en op vrijwel alle terreinen laat zich in de vakgroep dagelijks het externe aspect-specificeren gevoelen.

2. De betrokken groep valt duidelijk in ten minste twee delen uiteen: in studenten en in staf.

De eersten waren slechts na enige aandrang te bewegen de hun toekomende zetels in het vakgroepbestuur te bezetten. Voor de laatsten betekende het in. stellen van de vakgroep het opgaan van twee instituutsbesturen in één wat groter geheel, met een zeker identiteitsverlies dat eigen is aan alle fusies. De studenten - zowel als de stafleden in het vakgroepsbestuur hechten beide naar mijn indruk echter wel degelijk belang aan vakgroepautonomie. Ook hier gaat het om een moreel belang. Een direct materieel belang bij het zelf goed sturen en regelen van de vakgroepen hebben ze niet.

3. Het is moeilijk de transformationele eisen waaraan de vakgroep moet vol. doen, het contract met de omgevingssystemen, te vertalen in grootheden die door alle partijen als relevant worden herkend en erkend, al geldt dit uiter. aard minder voor het onderwijs dan voor het onderzoek.

4. Er is nauwelijks of geen sprake van een monitorsysteem voor tweezijdige bewaking van het contract. Er zijn slechts enkele, weinig samenhangende en vaak niet meer dan embryonale elementen van een beheers-informatie. systeem.

5. Er vindt zeer regelmatig en frequent in tal van verbanden werkoverleg plaats. Er is in dit opzicht eerder sprake van rituele óverinstitutionalisering dan van onderontwikkeling.

6. Zoals ik al opmerkte is de reële stuur en regelruimte zeer beperkt en bestaat de indruk dat deze ruimte nog steeds verder wordt ingekrompen. Van autonomie is in dit geval nog niet zoveel terecht gekomen.

\section{Ervaringen elders}

1. Uit de vrij omvangrijke literatuur over autonomiseringsexperimenten in Ne. derland komt naar voren dat de, zojuist al bij PTT gesignaleerde, aarzelende houding van topmanagement en vakorganisaties zeer algemeen is. In Scandinavië daarentegen, waar zowel in het particuliere bedrijfsleven (Volvo, Saab enz.) als in grote overheidsorganisaties (PTT, Spoorwegen enz.) van een ware autonomiseringsbewéging gesproken kan worden, hebben topmanagement en vakorganisaties een uitgesproken positieve houding.

3) Universiteit van Amsterdam FSW a, vakgroep Bestuurskunde en Publiekrecht. 
Het midden-en lager kader staat overál, zowel in Nederland als in Scandinavië, aanvankelijk wantrouwend tegenover het autonomiseringsstreven.

2. Moreel belang alléén lijkt zelden voldoende. In Nederland wordt aan succesvol zelfmanagement soms wel, soms geen materieel belang voor de betrok. kenen verbonden. In Scandinavië is er meestal wèl in enigerlei vorm een ma. terieel belang aan gekoppeld.

3. Het ontbreken van een voor alle partijen herkenbare en aanvaardbare normatiek, vooral in indirect-produktieve organisaties (non-profit organisaties, overheid) is vaak een struikelblok. In de V.S. en in het U.K. signaleert men met name op deze gronden het stuklopen van MBO en PPB projecten.

4. Als mijn eigen indruk voeg ik hieraan toe dat, zeker in Nederland, het construeren van passende monitorsystemen slechts zelden voldoende aandacht krijgt.

5. Mede als gevolg van het ontbreken van een goede normatiek en van een goe. de monitoring mist het werkoverleg vaak een minimum aan harde basis, waardoor het zweverig en vrijblijvend wordt. Management noch personeel nemen het dan serieus.

6. In Nederland worden aan de werkgroepen vaak weinig door hen als reëel en betekenisvol ervaren stuur- en regelbevoegdheden gegeven.

Ik heb geen idee hoe de opvallende verschillen tussen Scandinavië (De Sitter '75) en ons land zijn te verklaren, waar er op het eerste gezicht toch zoveel overeenkomstige maatschappelijke, politieke en culturele condities vervuld lijken te zijn. Het zou mijns inziens zeer de moeite waarde zijn hiernaar eens een onderzoek in te stellen.

\section{Samenvatting en perspectiof}

Eerder in mijn betoog wees ik er al op, dat mijn opsomming van succesvoorwaarden of succesbevorderende factoren mogelijk wat tautologisch zou kunnen aandoen. Ik heb immers in mijn rijtje van zes als laatste twee genoemd:

- geïnstitutionaliseerd overleg en

- werkelijke bevoegdheden.

De reden was dat er in veel concrete gevallen pas bij nader inzien blijkt geen echt geïnstitutionaliseerd overleg te zijn, waaraan in principe de gehele groep kan deelnemen, en dat er voor de groep in feite geen als reëel en betekenend gevoel. de stuur. en regelmogelijkheden bestaan (Ramondt '74, Schouten '74, Kastelein '74). Hier wordt dan voorbijgegaan aan het gegeven dat niets zozeer de autonomisering bevordert als het ook werkelijk géven van autonomie. Wil men deze elementen tòch buiten de lijst van succesfactoren houden, dan blijven dus over:

1. externe steun vanuit machtscentra in de omgeving (management, vakorganisaties),

2. behoefte aan zelfuerwerkelijking in het werk bij de betrokkenen,

3. duidelijke normen en

4. een goed signalerend monitorsysteem.

De laatste twee factoren hebben belangrijke arbeidsanalytische, econometrische, informatie technische e.d. aspecten, die doen verwachten dat ook in situaties waarin op dit moment nog géén gemakkelijk herkenbare grootheden kunnen worden aangewezen, waaraan de effecten van goed of slecht sturen en regelen 
kunnen worden afgelezen, dit morgen wèl kan. Immers ten aanzien van deze aspecten staan de ontwikkelingen niet stil. Ook in de overheidssfeer begint, hoe moeizaam ook, op dit punt iets van de grond te komen. Ik denk bijvoorbeeld aan de activiteiten van de $\mathrm{COBA}^{4}$ ).

Wèl wordt helaas het zicht op de essentiële functie van de factoren normatiek en monitorsystematiek vaak vertroebeld door de modieuze misvatting, dat nondirectieve agogische hulp aan de betrokken groepen alléén reeds voldoende is om ze tot autonomie te brengen. Maar door de cultuur van een organisatie of, sterker nog, van een organisatie-onderdeel te veranderen, veranderen immers niet automatisch de structuur en de technologie. Hiervoor is óók methodisch ingezette in. houdelijke expertise vereist.

Wat betreft de behoefte aan zelfverwerkelijking in het werk, zie ik in het alge. meen nog nauwelijks een smaller worden van de kloof tussen enerzijds deze $b e$ hoefte (latent of manifest) en anderzijds de feitelijke identificeringsmogelijkheden die zich in een groot deel van de werksituaties voordoen.

Naarmate de materiële levensomstandigheden optimaler worden en de opleidings. en vormingsvoorzieningen verder blijven toenemen en tegelijk de verhoudingen in de werksituaties weinig wezenlijk veranderen, zal deze tendens duide lijker worden. Ik denk dat wanneer zich dàn achtergrondgebeurtenissen voordoen, die de geloofwaardigheid of de legitimiteit van de basisprincipes van ons organisatiebestel doen wankelen, die kloof voor grote groepen volstrekt onduldbaar zal worden, waardoor zich belangrijke verschuivingen kunnen voordoen.

De Vietnam-affaire in de tweede helft van de 60'er jaren heeft, vooral voor de inrichting van de universiteiten in onze westerse wereld, een dergelijke functie gehad. Andere calamiteiten b.v. van macro-economische aard (crisis) of plaatsvindend in ons aller fysieke of morele milieu (Watergate, Lockheed) kunnen ook in de toekomst zo'n uitwerking hebben. Begrijp mij goed: ik heb geen voorkeur voor schoksgewijze sociale en organisatorische veranderingen, integendeel, maar ze is nog wel steeds de meest vóórkomende, al zou het percentage organisatieliteratuur over organische ontwikkeling anders doen vermoeden. Ik denk dat dit eerder evenredig is aan het percentage schoksgewijs opgelegde organisatieveranderingen, zelfs als we een correctie uitvoeren voor inkrimping en sluitingen als gevolg van de huidige recessie. (Zie ook Luscuere '75)

Tenslotte komen we dan aan de factor: steun vanuit topmanagement en vak organisaties. Afhankelijk van de ruimheid van visie die ze ontwikkelen, zal hun steun òf autonoom groeien òf worden afgedwongen. Dit is een optimistische schatting. $\mathrm{Er}$ is namelijk nòg een, en wel een zeer somber, alternatief: een totalitaire organisatiemaatschappij, waarin mensen en groepen met sophisticated psychisch en fy. siek geweld op hun onmondige plaats worden gehouden. Eenvoudig omdat ik zelf in zo'n wereld niet wil leven ben ik gemotiveerd om, wáár zich de gelegenheid voordoet, mijn bijdrage te leveren aan autonomiseringsprojecten. (Zie ook Hutte '76, p. 16)

In voorkomende gevallen zèlfs als aan die eerste voorwaarde, van externe steun, nog niet in toereikende mate is voldaan, namelijk als er een gerede kans bestaat dat het project de betrokken groep zodanig activeert, dat de externe

1) Commissie voor de Ontwikkeling van Beleidsanalyse. 
machtscentra de noodzaak tot autonomisering alsnóg zullen herkennen en erkennen.

Ik zie het voor organisatiekundigen, bedrijfskundigen en bestuurskundigen als een geweldige uitdaging om mee te helpen aan de theoretische maar vooral ook praktische beantwoording van de vraag:

- hoe kunnen we centrale aspectspecificatie overal in onze samenleving tot een minimum beperken, zonder ons uit te leveren aan het vrije spel der maatschap. pelijke krachten?

Tenslotte, ik ben me ervan bewust dat ik in mijn betoog belangrijke zaken heb laten liggen, zoals:

- òf, en zo ja wèlke, consequenties de door mij geschetste autonomisering en democratisering op micro niveau zou kunnen hebben voor de bestaande economische, sociale en politieke orde op meso- en macro niveau;

- en in het bijzonder of ze bepaalde veranderingen in die orde in de hand zou kunnen werken of juist zou kunnen blokkeren.

Ik hoop hierop bij andere gelegenheden nader te kunnen ingaan.

Geraadpleegde literatuur m.b.t. participatiebevordering en democratisering op en rond de werkplek ${ }^{5}$ )

I. Theorie en opinie

1. C. J. Lammers e.a. - Medezeggenschap en overleg in het bedrijf - Marka '65

2. Emery, Thorsrud, Trist - Form and content in industrial democracy - Van Gorcum-Tavistock '69

3. Frieder Nachold - Organisatie en democratie - Spectrum '70

4. Paul Blumberg - Democratie in het bedrijfsleven - Marka ' 71

5. Landelijke Economen Konferentie 1970. Democratisering en efficientie? - Wolters Noordhoff ' 71

6. a. A. van Vliet - Een taakgericht groepsexperiment - Interaktie nr. 3, '71

b. W. Top - Werkstructurering is een bedrijfsekonomische kwestie - Interaktie nr. 3, '71

Richard Schacht - Alienation - Allen and Unwin' 72

8. Mens en Ondememing - speciaal nummer: Ondernemingsdemocratie: mode of model? - nr. 3, '73

9. G. A. J. de Vos en A. Walraven - Werkoverleg, een nieuwe fopspeen? Personeetbeleid 9, nr. 7/8, '73

10. M. R. van Gils - Democratisering in bedrijven - Bedrijfsvoering nr. 10, '74

11. J. J. M. Hendriks - Een systeemtheoretische beschouwing over democratie - Sociologische Gids, jan. '74

12. Informatief no. 8 - Bureaucratie, democratisering, werkoverleg - Stichting $M$ en $O$ '74

13. Carole Pateman . Participation and democratic theory . Cambridge ' 74

14. Eric Rhenman - Bedrijfsdemocratisering en bedrijfsvoering - Samsom ' 74

15. Studieproject Gelijkheid, rapp. nr. 9: op weg naar arbeiderszelfbestuur - Wiardi Beckman Stichting '74

16. a. J. Kastelein . Enkele uitgangspunten en rolvoorkeuren van de moderne organisatiespecialist . MAB, dec. 72

b. J. Kastelein. Taakstelling en deelneming in complexe organisaties MAB, jan. '73

c. J. Kastelein - Sociologen en organisaties - Bedrijfskunde nr. 2, '75

17. J. H. Kuipers - Beleidsvoering door werkoverleg - Samsom '75

18. C. Luscuere - Over veranderbaarheid en bewaakbaarheid van organisaties - ESB, 15 jan. '75

19. P. J. van Strien e.a. - Vervreemding in de arbeid - Boom '75

20. W. Albeda - Participatie, arbeid en maatschappij - Samsom '76

21. H. A. Hutte - Wat is er sociaal aan de werkelijkheid? . Tj. Willink - afsch. coll. '76

22. Arne F. Leemans - A conceptual framework for the study of reform of central government - in: The Ma. nagement of change in government - Martinus Nijhoff' 76

23. Marshall Sashkin. Changing toward participative management approaches: a model and methods - Academy of management Review, vol. nr. 3,'76

24. Daniël Tarschys - The organizational response to governmental overload - Paper EGPA - workshop, Betin '77

\footnotetext{
5) In volgorde van jaar van publicatie en per jaar in alfabetische volgorde van auteursnaam, met als uitzondering dat werken van een auteur die meermalen over hetzelfde onderwerp publiceerde in het laatste publicatiejaar zijn genoemd.
} 
II. Onderzoek en theorievorming op basis van onderzoek

J A. P. van Hoof . Autonomie en motivatie van arbeiders in industriële bedrijven · diss. '64

V. Vroon - Work and motivation - New York ' 64

v. Beinum, v. Gils en Verhagen - Taakontwerp en werkorganisatie - COP.SER '68

P. G. Herbst Autonomous group functionering - Tavistock '68

5. Guido B. Cohen The task-tuned organization of groups - Swetz en Zeitlinger '69
6. J. L. J. M. van der Does de Willebois - a. Werkstructurering als organisatie ontwike

b. Onderneming en autonomie, in Wordende Wereld, sept. '71

7. J. H. Kuipers - Verantwoordelijkheidsverruiming in de directe werksituatie - COP.SER '72

8. A. H. van der Zwaan - Leveren en laten leveren - Univ. Pers. R'dam '79

9. L, U. de Sitter e.a. - Technologie en organisatie - Samsom '74

10. a. J. J. Ramondt - Verantwoordelijkheid in het werk Samsom '68

b. J. J. Ramondt - Bedrijfsdemocratisering zonder arbeiders - Samsom '74

11. a. J. Schouten . Vrijheid in het werk en inspraak in het bedrijfsgebeuren THE '79

b. J. Schouten . Vrijheid in het werk - Boom ' 74

12. a. J. Kastelein - Taken en taakcontacten - diss. '70

b. J. Kastelein - Organisatieveranderingsprojecten -in J. A. A. v. Doorn - Projectorganisatie - Univ. Pers R'dam '7 1

c. J. Kastelein . Een evaluatie van het $\mathrm{T}$ en $\mathrm{D}$ - project in de telefoondistricten - Interne publicatie PTT CAORG, mrt '74

13. Gerard Endenburg Sociocratie - Zaandijk '75

14. L. U. de Sitter Werkoverleg en werkstructurering in Zweden - NIVE publ. 604, '75

15. F. C. A. van Haasteren en M. van Overeem - Arbeid a la carte - SMO april '76

16. A. L. A. van der Bruggen en J. F. den Hertog - Werkoverleg op afdelingsniveau - Mens en Onderneming nr. 6,76

17. J. F. den Hertog - Werkstructurering, ervaringen met alternatieve werkorganisaties binnen het Philipsbe drijf diss. '76

18. C. W. van der Touw - Participatie in het werkoverleg - TH Delft, mei '76

19. Human Relations - Special issue: Participation and industrial democracy - vol. 29 nr. 5 , '76

20. J. in 't Veld - Arbeidsplaats en organisatie - TH Delft '76

21. Ray Wild . Groepswerk in massaproduktie Bedrijfsvoering - nr. 6, '76

22. Bolweg, Van der Graaf, Van der Touw en Scholten - Speciaal nummer over medezeggenschap - Mens en onderneming - nr. 1, '77

23. - Mauk Mulder

a. Het spel om macht - Boom '72

b. Omgaan met macht - Elsevier ' 77 